\author{
Jean Luc Erero \\ (iD) https://orcid.org/0000-0002-7901-3108 \\ Operational Research (OR) \\ Tax, Customs and Excise Institute (TCEI) \\ South African Revenue Service (SARS) \\ JErero@sars.gov.za
}

\title{
The effects of illicit cigarette trade in South Africa: A CGE analysis
}

Accepted by Editor Ewa Ziemba | Received: July 23, 2019 | Revised: March 9, 2020; March 20, 2020 | Accepted: March 24, 2020.

\begin{abstract}
Aim/purpose - This paper evaluates the effects of the illicit cigarette trade on the South African economy through a static Computable General Equilibrium (CGE) model. Indeed, the illicit cigarette trade occupies a prominent place in public debate in South Africa.

Design/methodology/approach - The base year Social Accounting Matrix (SAM) of the model is constructed from the data for 2015 to reflect the most recent information. The model includes a number of direct and indirect tax variables. The indirect tax section is decomposed into VAT, excise and fuel levy for analysis purposes. The household section considered all income categories with 14 distinct deciles.

Findings - One policy simulation was carried out to evaluate the effect of the illicit cigarette trade on growth and income distribution. Our findings show that the loss of R8 billion in tax revenue given the current growth of the illicit cigarette market has impacted negatively on the country's GDP and employment rate.

Research implications/limitations - We utilised the latest available data for 2015 when constructing the SAM that was used as database for the model. The assessment of the illicit cigarette trade through the application of a CGE model provided strategies for the implementation of a specific Cigarette Governing Body, with distinct areas of accountability focusing solely on illicit cigarettes.

Originality/value/contribution - There is a need for urgent attention from the state to combat the trade in illicit cigarettes, as most of this illegal product is produced in South Africa. This paper contributes by expanding awareness amongst policy makers and the public regarding the connection between the illicit trade in licit goods, corruption, and organised criminal networks.
\end{abstract}


Keywords: illicit cigarette, CGE model, South Africa.

JEL Classification: C68, E26.

\section{Introduction}

South Africa is eluding 10\% of its Gross Domestic Product (GDP) annually, approximately R178 billion every year, to its 'illicit economy', which has raised serious concerns among the successful economic agents in the country. The main concern relates to the smuggling of cigarette merchandise, counterfeit textiles (originating especially from China in conjunction with the trafficking of drugs through South Africa's leaky frontiers), and the illicit mining of gold and diamonds (Stats SA, 2017).

This illicit commerce can be depicted as the contravention of established laws which describe legal rules to observe when trading specific products, such as cigarettes, diamonds and gold. Usually these illicit products are smuggled for the simple reason of avoiding paying taxes or duties (Herald, 2015).

Haysom (2019) pointed out that illicit cigarette commerce in South Africa occupies a prominent place in southern African politics, due to its prominent role in the 'state capture' scandals that characterised politics in South Africa between 2013 and 2018. Indeed, the illicit tobacco trade occupies a prominent place in public debate in South Africa, both regarding crimes that may have been committed in the last five years, and about how the current administration is responding to the illicit economy in the present. Thus, eradicating the practices of smuggling illicit cigarettes remains a major feature of South Africa's political economy.

A recent study conducted by the Tobacco Institute of Southern Africa (TISA) revealed that South Africa loses R8 billion in tax revenue given the current growth of the illicit cigarette trade. Consequently, South Africa has become the first country in the world in which the biggest brand in the tobacco industry is the illicit cigarette. Between June and October 2018, the sales of illicit cigarettes increased substantially from $33.4 \%$ to $41.8 \%$. This means that one in every three cigarettes is sold below the minimum collectable tax (TISA, 2018).

The RG brand, produced by Gold Leaf Tobacco Corporation (GLTC), is classified as occupying the number one spot in sales in South Africa, outselling all other brands. This includes Peter Stuyvesant, which was the leading brand in South Africa for decades. Nonetheless, $89 \%$ of RG products retail for less than R17.85 per pack, but are now averaging R10 per pack. Recently, the RG brand has expanded its distribution into five of the country's nine regions. Subsequently, 
the distribution of the products tripled in the Northern Cape and doubled in KwaZulu-Natal, while sustaining a strategic distribution in other regions. Out of every packet of cigarettes sold in the local market, a tax amount of R17.85 is paid to the South African Revenue Service (SARS). This amount is further subdivided into excise duty (R15.52) and VAT (R2.33) as pointed out by Haysom (2019).

In addition, there are cigarette packs that sell for as little as R5 in the market. Loose sticks, which sell for just 50 cents, are on the rise because the traders who are selling at R1 are becoming 'less popular'. Indeed there is a need for urgent attention from the state, as most of the illegal product is produced in South Africa (GLTC, 2018).

This paper evaluates the effects of the illicit cigarette trade in South Africa, as the illicit trade in licit goods supports organised crime and corruption, and erodes state structures. Section 2 covers the literature review and the overview of the illicit cigarette trade; section 3 refers to the methodology utilised; section 4 offers the simulation results; and section 5 summarises the paper.

\section{Literature review}

\subsection{Survey of previous empirical studies}

The illicit cigarette trade is enormous - it is assessed that one in every ten cigarettes consumed worldwide is illicit. In Australia, for example, the illicit market encompasses roughly $3.8 \%$ of total cigarette consumption. Amongst other researchers, KPMG (2018) has found that illicit cigarettes in Australia account for $14 \%$ of total consumption, causing the Government an assessed revenue loss of about $\$ 1.6$ billion (R22.3 billion) per year. Rohan Pike Consulting (2017) assessed the size of the illicit cigarette market in the same country at $\$ 3.8$ billion (R52.9 billion) per year.

Since an increase in excise duties in Australia, cigarettes have become more precious by credence than silver, thus illicit cigarettes are the most gainful economic activity. The illicit cigarettes are smuggled in from abroad, especially from countries with minimal or no cigarette excise duties (Bankman \& Schler, 2007).

In the UK, despite the strong law enforcement in the traffic of illicit cigarettes, the government continues to introduce new strategies to combat this trade. Recently, British lawmakers successfully implemented a 'From Leaf to Light' strategy, which led to a decline in the size of the illicit cigarette market from $22 \%$ of the market in $2000 / 01$ to $10 \%$ in $2013 / 14$, and the illicit hand-rolling 
tobacco market from $61 \%$ to $39 \%$ over the same period. Moreover, the emphasis on active and harmonised enforcement was seen as the most successful outcome of this strategy (Herald, 2015).

In Zimbabwe, between $19 \%$ and $35 \%$ of the population of 16 million people smoke. British American Tobacco (BAT) has a factory that produces cigarettes for the Zimbabwean market and neighbouring countries, as does Savanna Tobacco and Gold Leaf. Both of these latter companies have their main markets in South Africa. Recently a few more tobacco companies were set up in Zimbabwe, but their ownership and the nature of their products is unclear (Malcolm, 2013).

The prices of tax-paid cigarettes in Zimbabwe differ according to the brand; the range is between $\$ 1.20(\mathrm{R} 16.7)$ and $\$ 1.60$ (R22.3) per pack. The cost of a loose cigarette sold at a retail outlet varies from $\$ 0.06$ (R0.8) to $\$ 0.17$ (R2.4). The price of a pack of cigarettes on the black market is a third of the price of a pack on which full taxes have been paid. There is, therefore, a burgeoning domestic illicit market in Zimbabwe, but according to one informant in South Africa, "In the past, independent factories in Zimbabwe existed only in order to smuggle to South Africa" (Haysom, 2019).

Zimbabwe-produced cigarettes are smuggled into all its neighbouring countries, with the clear majority being smuggled into South Africa. The exact scale and number of cigarettes smuggled is unknown, yet our interviewees were unanimous in their belief that large quantities of cigarettes are smuggled into South Africa daily. The majority of seizures of illicit cigarettes in South Africa have been of Pacific and Gold Leaf, both brands made by the Savanna Tobacco company (African Tax Outlook, 2018, pp. 58-60).

According to Vellios \& van Walbeek (2016), there is vast evidence that higher cigarette prices diminish tobacco consumption, with substantial diminutions among youngsters, females and those who live in the extreme poverty. Extensive evidence proposes that the price elasticity of demand for cigarettes differ broadly, with developing countries holding greater price elasticity (Abedian \& Jacobs 2001).

Mukong \& Tingum (2018) estimated the price elasticity of demand for cigarettes in South Africa, a country that has presently be subjected to a transition in the cigarette market, from a near monopoly to a more competitive market structure. They found a negative price elasticity of demand for cigarettes, with the total price elasticity significantly larger than the conditional elasticity.

The latest inclusive review by Rezayatmand, Groot, \& Pavlova (2017) singled out disturbingly some studies that applied individual-level data to measure the demand for cigarettes in under-developed countries. Most of the studies that 
applied aggregate time-series data are faced with serious challenges when analysing the effect of price change on smoking involvement due mainly to the behaviour of each individual. In econometrics, these variables are considered as constant and are supposed to ensure no bearing on the demand for cigarettes. Becker \& Murphy (1988) indicated that the main hypothesis could be the smoking addiction, which could portray an important role in establishing the demand for cigarette. Although the omission of these variables facilitates the assessment of the demand for cigarettes, but unfortunately conceals significant facts that could influence the estimates of price. In this respect, it is required that these variables be included for accuracy purposes when estimating the price elasticity and its effect on cigarette use.

The elasticity of demand for cigarettes is usually lower in industrialised countries than in under-developed countries. Huang \& Yang (2006) found that in the United States (US) the elasticity of demand for cigarettes varies between -0.005 to -0.62 , while Coats (1995) found that the price elasticity varies between 0.005 and 0.016 in the US when applied the aggregated panel data to estimate the price elasticity. Guindon, Paraje, \& Chaloupka (2016) indicated that on average, the price elasticity of demand for cigarettes is approximately -0.5 for under-developed countries as assessed from the 32 studies from Latin America.

Evidence from various countries indicates that most studies used the Econometric techniques to estimate the elasticity demand for cigarettes. This paper will therefore add value in the academic world by using the Computable General Equilibrium model to analyse the impact of the illicit cigarettes on the South African economy.

\subsection{Overview of the tobacco industry in South Africa}

A recent study conducted by TISA (2018) indicated that the tobacco industry in South Africa amounts to R29 billion and contributes approximately R17.2 billion in excise duty and VAT per year. It is estimated that the industry is an employer to around 108,500 individuals.

The industry is subdivided into two main industries, namely unprocessed and processed goods. The unprocessed industry includes farming characteristics, such as traditional farming, harvesting, categorising, curing and supplying of output products to a manufacturing factory. The players in the unprocessed industry of the tobacco market include farmer co-operatives and tobacco wholesalers. The processed industry consists of the manufacturing and supplying of 
the final manufactured products (cigarettes, snuff and pipe tobacco) to the customer (Malcolm, 2013). The structure of the market value chain for the tobacco industry is illustrated in Figure 1 below.

Figure 1. Structure of the market value chain for the tobacco industry

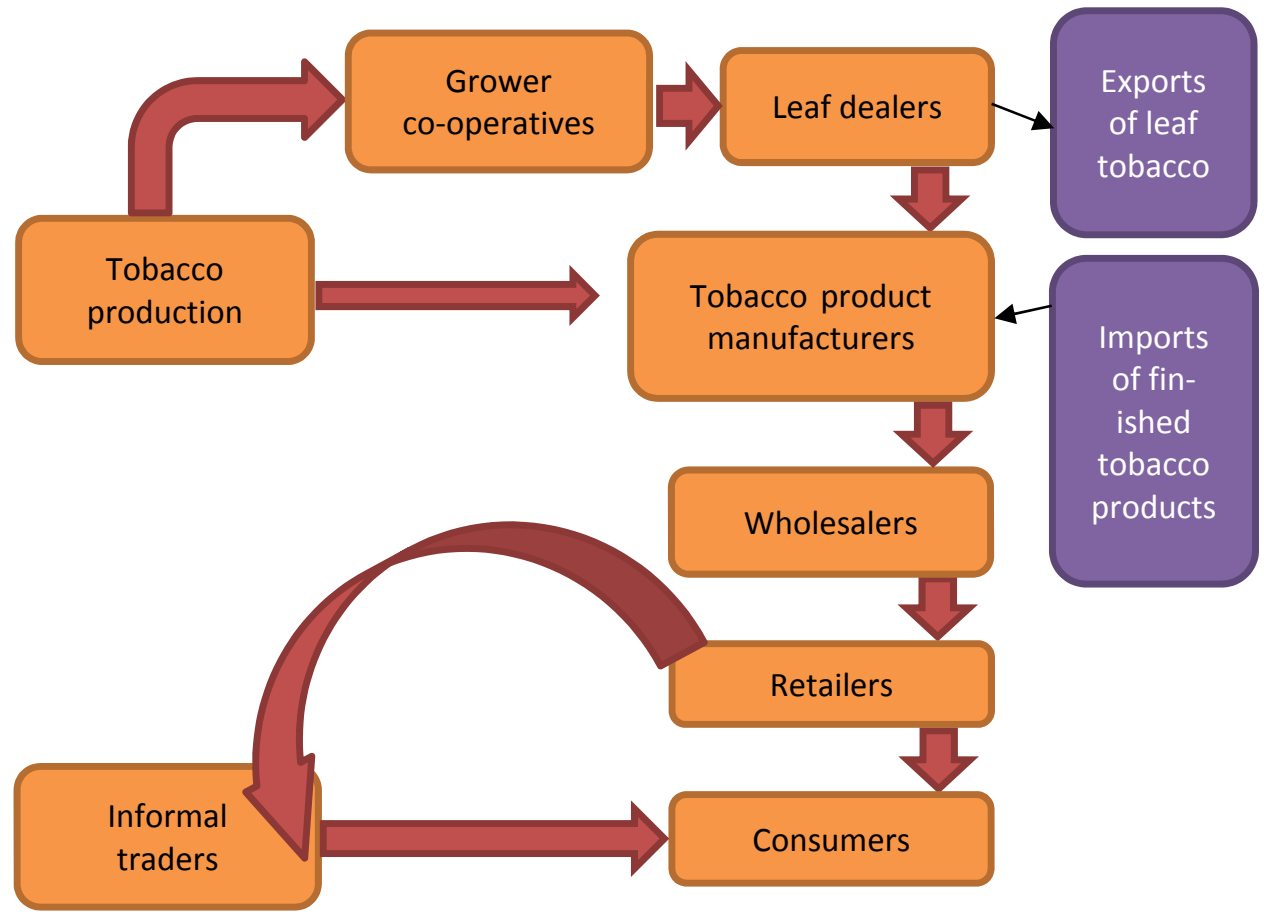

Figure 1 indicates that South Africa supplies two sorts of tobacco, described as Flue Cured Tobacco (FCT) and Air Cured Tobacco (ACT). The former, FCT, is specifically utilised for cigarettes, while the latter, ACT, is specifically utilised as snuff, pipe tobacco and roll your own cigarettes (RYO). In 2018, South Africa produced approximately 8 to 10 million $\mathrm{kg}$ of FCT for domestic consumption. In contrast, during the same period, the production of ACT contracted by 2 to 3 million $\mathrm{kg}$, of which $70 \%$ to $80 \%$ is utilised for domestic consumption (TISA, 2018).

Haysom (2019) indicated that the final manufactured tobacco products are supplied across 364 wholesalers, 55,000 retailers, and some 660,000 street vendors and 'spaza' shops in the informal sector. Similarly, the tobacco industry is in charge of the importation and exportation of final manufactured tobacco products.

The tobacco industry is dominated by the largest producer of cigarettes, British American Tobacco (BAT), which produces approximately 27 billion cigarettes per year. Its production meets the demand for both internal and exter- 
nal markets, with a substantial domestic market share of around $85 \%$. Other players include domestic firms such as Carnilinx (Pty) Ltd. which produce some inexpensive brands, while famous brands such as Chesterfield and Marlboro are imported solely by Philip Morris South Africa (Pty) Ltd. (BAT, 2019).

The provinces where tobacco is grown in South Africa are Limpopo, the Western Cape, Mpumalanga, North West and the Eastern Cape. According to a report by Euromonitor International (2017), the patterns of cigarette sales show that the generated revenue from tobacco gradually dropped in 2017. The main reasons for this could be that the economy developed poorly and the government introduced a programme to discourage smoking. However, the decline in volume sales is reported to have been moderated by a substantial improvement in the production rates of smaller producers of tobacco.

There is also an emerging trend of an increasing number of consumers who are switching to vapour products. The competition amongst retailers who distribute these products seems to be benefiting consumers due to their cheap prices and the accessibility of the products. Another concern for sellers of cigarettes relates to the hijacking of vehicles conveying legal tobacco products, with a trend of approximately 1,400 hijacked vehicles per annum (World Health Organisation [WHO], 2019).

With respect to trade, there has been a consistent decline in the Customs values of tobacco products in the past three years, dropping from R18 billion in 2015/16 to R16.7 billion in 2017/18. However, the number of declarations made, VAT, and Customs duty paid increased in the same period (Haysom, 2019).

Furthermore, there has been a substantial drop in the number of seizures made by SARS, declining from 306 in 2015/16 to 205 in 2017/18, with the number of cigarette sticks seized dropping more than threefold from 49.7 million sticks to 10.2 million sticks in the same period. The value of cigarette sticks seized reduced from R48.5 million in 2015/16 to R11.1 million in 2017/18 (SARS, 2018).

\subsection{Cigarette revenue collection in South Africa}

Recently SARS implemented several strategic programmes to restrain revenue leakages deriving from prohibited and depraved transactions in the illicit cigarette trade, which largely originated in the informal sector by established crime syndicates. 
South Africa is experiencing considerable losses in excise revenue because of an expansion in the manufacturing, distribution and commerce of illicit excisable items. Despite this defy, SARS has created a plan to lessen the illicit and non-compliant transactions through implementation of new policies and strategies. This is done through usage of improved technology to exclusively promote certain products, with the aim of maximising the production and distribution of final products. New SARS track-and-trace marker technology will be introduced into the cigarette commerce, which will allow SARS to control the production system of cigarette from the fabricating plants to consumers. This new strategy will enhance the collection of tax revenues.

Sharp excise tax increases since 1990 have stimulated a large diminution in consumption and a rise in government revenue. However, from 2015 to 2018, the volume of tax-paid cigarette sales recorded by the Department of National Treasury decreased by $23 \%$. Poor economic performance does not explain this decrease, however, as prevalence estimates are still approximately $20 \%$. Figure 2 includes the revenue collected for tobacco and manufactured tobacco substitutes, cigarette paper, artificial cellulose acetate, machinery for preparing or making up tobacco, cigars, cheroots, cigarillos and cigarettes during fiscal years 2014/15 and 2017/18. The trade patterns, including quantities and values of imports, are analysed for the past nine years (SARS, 2018).

Figure 2. Revenue collections in millions rand

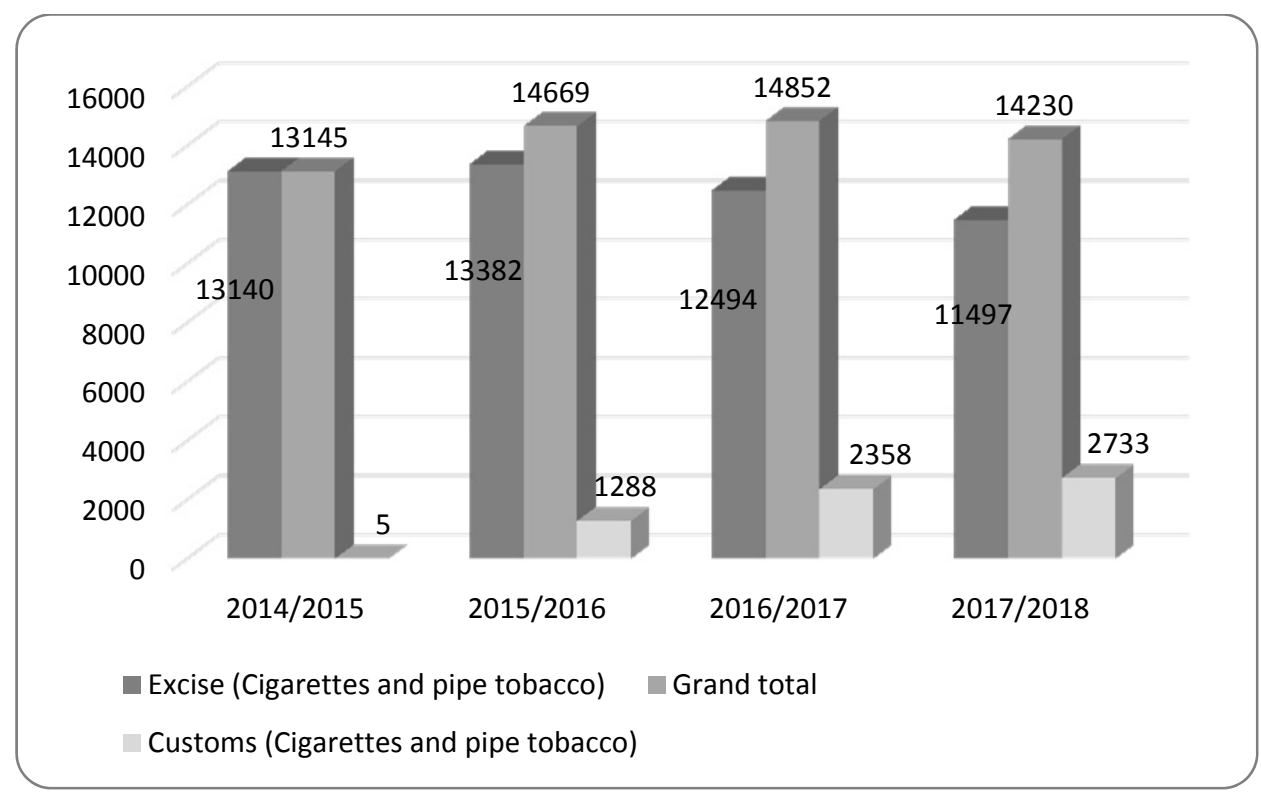

Source: SARS (2018). 
Figure 2 indicates that total revenue collected for the cigarette trade has been drastically decreasing, dropping from $12 \%$ in $2014 / 15$ to $4 \%$ in $2017 / 18$. This has been largely attributed to the decrease in Excise revenue, which reduced from R13.1 billion in 2014/15 to R11.5 billion in 2017/18. In contrast, Customs revenue has consistently been increasing, growing from $0.04 \%$ in $2014 / 15$ to $19.21 \%$ in $2017 / 18$. It must be noted, however, that Customs revenue excludes VAT on imports because of the inclusion of all other tariffs.

The total revenue collected is directly correlated with Excise collections as it contributes $89 \%$ to the total cumulative collection, as illustrated in Figure 3. The remaining $11 \%$ is derived from the customs' revenue collections from cigarettes and pipe tobacco.

Figure 3. Revenue contribution per tax type

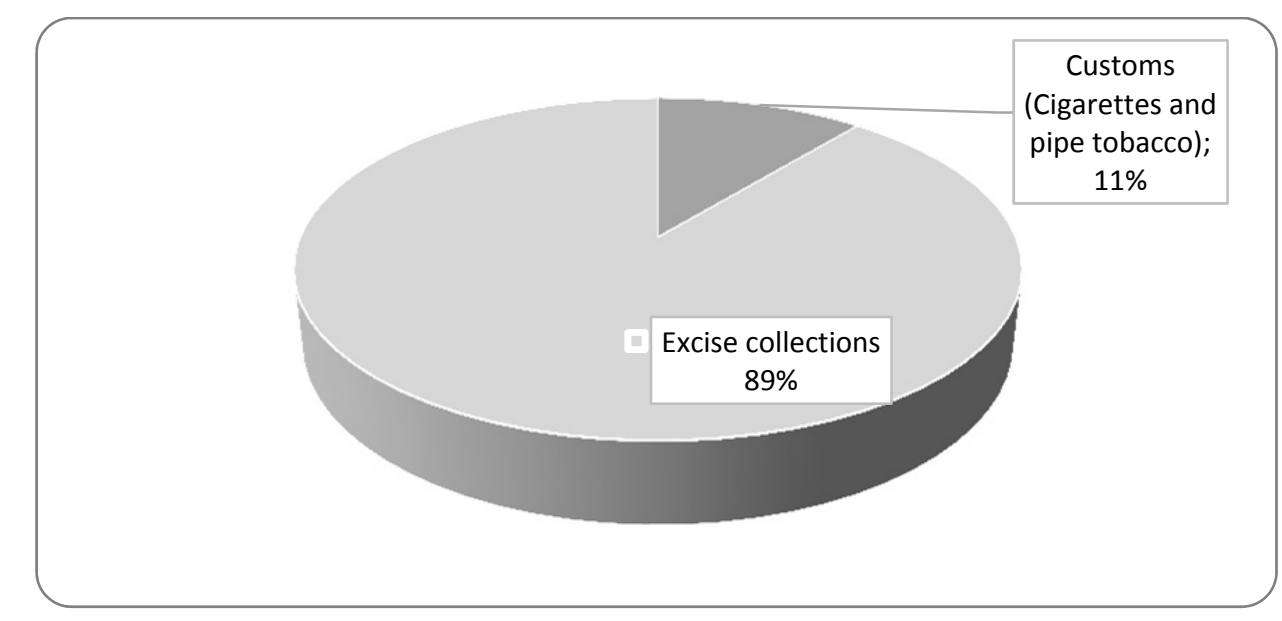

Source: SARS (2018).

Table 1 includes the customs value and revenue declared for tobacco and manufactured tobacco substitutes between 2010 and 2018 .

Table 1. Tobacco and manufactured tobacco substitutes

\begin{tabular}{|l|c|r|r|c|}
\hline Fiscal Year (FY) & Customs Value Declared & VAT Declared & Duty Declared & Total Revenue Declared \\
\hline FY2010 & $6,643,765,445$ & $71,805,510$ & $169,753,488$ & $241,558,998$ \\
\hline FY2011 & $6,385,718,827$ & $64,571,705$ & $236,435,033$ & $301,006,737$ \\
\hline FY2012 & $9,413,962,056$ & $199,752,809$ & $555,229,677$ & $754,982,486$ \\
\hline FY2013 & $11,366,124,162$ & $321,432,647$ & $1,083,351,519$ & $1,404,784,166$ \\
\hline FY2014 & $15,112,974,021$ & $342,006,012$ & $1,133,197,407$ & $1,475,203,419$ \\
\hline FY2015 & $18,249,561,428$ & $339,383,555$ & $864,817,234$ & $1,204,200,789$ \\
\hline FY2016 & $19,853,869,792$ & $450,594,999$ & $1,367,876,507$ & $1,818,471,506$ \\
\hline FY2017 & $20,095,637,656$ & $715,085,867$ & $2,388,669,855$ & $3,103,755,722$ \\
\hline FY2018 & $18,994,337,733$ & $749,290,873$ & $2,784,148,710$ & $3,533,439,583$ \\
\hline
\end{tabular}

Source: SARS (2018). 
Table 1 indicates that the revenue extracted from the total customs value declared in the past nine years increased by $11 \%$ between the fiscal years 2010 and 2018. The extraction rate fluctuated from $4 \%$ in $2009 / 10$ to $19 \%$ in $2017 / 18$, however, the national extraction rate remained consistent at $15 \%$. VAT contributed $24 \%$ to the total revenue declared, while Customs Duty contributed $76 \%$ to the total. In comparison, Customs duty for tobacco and manufactured tobacco substitutes contributed $2.9 \%$ to the total trade, followed by customs value with a contribution of $1.07 \%$ and VAT with a contribution of $0.31 \%$. Table 2 includes the types of machinery and mechanical appliances used to manufacture cigarettes.

Table 2. Importation of cigarette manufacturing machines

\begin{tabular}{|l|r|r|}
\hline \multicolumn{1}{|c|}{ Description } & Customs value & Statistical quantity \\
\hline Machinery for making up tobacco, not specified & $625,790,773$ & 79,595 \\
\hline Machinery for manufacturing tobacco cigarette & $162,502,459$ & 7 \\
\hline Cigarette making machine & $111,440,150$ & 11 \\
\hline Machinery & $108,324,330$ & 523 \\
\hline Making \& packing machine model AM14x24350 & $29,248,011$ & 1 \\
\hline Other machinery & $306,340,438$ & $4,369,224$ \\
\hline Grand Total & $1,343,646,161$ & $4,449,361$ \\
\hline
\end{tabular}

Source: SARS (2018).

Table 2 indicates that over the past nine years, 4,449,361 counts of machinery to the customs value of $\mathrm{R} 1,343,646,161$ were imported. This machinery included nuclear reactors, boilers, mechanical appliances and machinery for manufacturing tobacco cigarette.

\subsection{Illicit cigarettes in South Africa}

The largest quantity of cigarettes being smuggled daily into South Africa originates from Zimbabwe. Trucks and fuel tankers are the main means used to smuggle cigarettes through the Beitbridge border (Beitbridge is located at the Limpopo River extending between South Africa and Zimbabwe), making use of the balance of trade discrepancy between the two countries. The majority of seizures of illicit cigarettes in South Africa have been Pacific and Gold Leaf, both brands made by the Savanna Tobacco company in Zimbabwe. The scam makes use of the fact that tankers could plausibly claim to be leaving Zimbabwe 'empty' after dropping off loads of fuel. Trucking companies also actively seek 
to defray their costs by filling otherwise empty vehicles with illicit loads. In fact, according to sources, during the heyday of cross-border cigarette smuggling in the late 1990s and early 2000s, some enterprising individuals even set up routes that brought licit goods to Mozambique, where 'empty' trucks would then be filled with second-hand clothes, which were then smuggled into Zimbabwe and replaced with cigarettes, which in turn were smuggled into South Africa. Since the introduction of the use of scanners on trucks by both countries, smuggling cigarettes has become higher risk for small-scale businessmen, due possibly to the lack of political protection (GLTC, 2018).

\subsubsection{Modalities}

According to Haysom (2019), the individuals involved in the smuggling of cigarettes from Zimbabwe to South Africa can be divided into two groups: organised low-level smuggling operations run by individual entrepreneurs or groups of entrepreneurs, and organised smuggling cartels with political protection who smuggle the largest loads of illicit cigarettes into South Africa.

\section{Small-scale smugglers}

Several informants have described the practices of small entrepreneurs who are in the cigarette smuggling business. These smugglers send men across the Limpopo River at informal border-crossing points in the bush. Small trucks and minibuses are hired for this purpose from Zimbabwe. Some of these vehicles have their seats taken out and their windows tinted to prevent people from seeing inside (OECD, 2017).

The process of offloading the cigarettes takes very little time. The cigarettes are brought to the various crossing points to get moved across the river by 'runners', who are mostly unemployed young men below the age of 40 . This is done at night, between midnight and 3:00 a.m., when most people are asleep. The 'runners' physically carry the cigarettes in plastic bags on their backs and cross the Limpopo River to South Africa. The soldiers who guard the crossing points on both sides of the border are bribed to look the other way.

The buyers on the South African side are businessmen who wait to pick up the cigarettes from the 'runners'. To get to their destinations, their trucks use small and private roads to avoid tollgates, roadblocks, and ad-hoc searches by law enforcement on main roads. 
People in the cross-border transportation business have noted that the scanners and other measures at the Beitbridge border crossing have made it risky for truck drivers to be involved in cigarette smuggling. Over time, this has led to greater use of informal border crossings by small-scale smugglers.

For those who continue to use the official border crossing at Beitbridge, buses with hidden compartments are used to smuggle cigarettes, as they are not scanned but only subject to sporadic road checks. Small cars are also not scanned, but former smugglers say that as they can only carry small volumes, the risks outweigh the potential gain, which means this is not a popular method of smuggling.

Drivers pay heavy fines to the South African authorities if caught smuggling, and in most cases, they end up losing their vehicles and hence their livelihoods. However, drivers are sometimes able to bribe their way out of trouble, and they allege that some police officers actively seek out illicit goods in order to extract bribes.

The South African police are considered to be periodically effective and harsh. If a smuggler is actually arrested, it is almost always on the South African area of the frontier, and they are taken to South African courts.

\section{The 'untouchables'}

There are also individuals involved in organised cigarette smuggling syndicates who are described by law enforcement as 'big people' who are 'untouchable'. A former smuggler claimed that one of these cigarette-smuggling cartels involves politicians at the highest levels of government in both Zimbabwe and South Africa, operating a smuggling scheme that runs from Harare to Durban. Huge trucks are used to smuggle the cigarettes from their loading points in Harare through formal border crossing points and onwards to their destination. These trucks are not stopped or searched on the Zimbabwean side of the border (Haysom, 2019).

The cigarette brands that are most frequently smuggled are Remington Gold and Pacific Blue, both of which are owned by Savanna Tobacco. Seizures at Beitbridge border post accounted for $82 \%$ of seizures of illicit cigarettes made in South Africa in 2016. However, in recent years there have also been seizures of Zimbabwean cigarettes, mostly Savanna's Pacific brand, on the South Africa-Botswana and South Africa-Mozambique borders (Euromonitor International, 2017). 
Savanna Tobacco is owned by a man who is married to the niece of former Zimbabwean President Robert Mugabe and appears to have enjoyed political protection during Mugabe's rule. His company has previously been implicated in tobacco-smuggling allegations; cigarettes manufactured by Savanna have been intercepted being smuggled across the border hidden in an array of different vehicles, including oil tankers and mobile horse stables, in which the product was hidden in secret compartments, false floors, and/or stashed amongst other stock (Herald, 2015).

Since the political transition, this man's position may have changed. Interviews with law enforcement in Zimbabwe confirmed that Savanna Tobacco has recently been ordered to pay tax it has failed to pay the state over the years. According to a former smuggler in South Africa, the owner of Savanna Tobacco has lost political protection and is also under financial pressure.

Another significant figure in the illicit cigarette trade is the owner of Gold Leaf Tobacco Corporation (GLTC), who has cigarette factories in South Africa and a tobacco-processing factory in Zimbabwe. He owns a suite of companies, including farms, mines in Zimbabwe and the Democratic Republic of Congo, a logistics company, and a bus company. He has residences in Zimbabwe, South Africa, and the United Kingdom.

\subsubsection{Government implications}

Before the introduction of democracy in South Africa, the Rembrandt Group was the only company that produced tobacco in South Africa. The owner of this company was an Afrikaner who benefited extensively from the apartheid government, and taxes on tobacco and cigarettes were virtually non-existent. Radical changes occurred when the new democratic government promulgated a law to try to curb the threat to public health caused by smoking in 1993. At the same time, higher taxes on cigarettes were implemented and Rembrandt was compelled to cede its market share to BAT, handing over what was a near-monopoly share of approximately 93\% (Aizenman \& Jinjarak, 2005).

Haysom (2019) pointed out that the share of smokers and cigarettes smoked in South Africa decreased substantially since the implementation of the Tobacco and Related Products Control Act. This decline has been credited to the increase of taxes on cigarettes, as well as a determined public health policy aimed at curbing smoking in public venues and raising awareness of the health hazards posed by smoking. The share of smokers in the population has been declining 
slowly in recent years, dropping to around $20 \%$ of the total population in 2017, thus companies now compete for a limited pool of consumers in South Africa. SARS should collect R17.85/\$1.50 tax (R15.52 in excise duties and R2.33 in VAT) per pack of cigarettes for the 2018/2019 year, based on the national budget. Any pack of cigarettes selling for less than R17.85 is assumed to be illicit; illicit cigarettes cost between R5 or R10 ( $\$ 0.40$ or $\$ 0.85)$ per pack. In fact, these cigarettes are readily available from the street vendors all over the country. The low price is an indication that illicit cigarettes are easy to purchase and popular amongst low-income buyers.

Estimates in 2002, when the illicit cigarette trade was growing, showed BAT's market share at between $86 \%$ and $95 \%$, however, more recent estimates put its market share at around $74 \%$, and large multinationals claim to have lost $10 \%$ of their market to illicit cigarettes in the last year alone. Other independent tobacco companies make up most of the rest of the market that is not controlled by BAT, several of which have been publicly accused of having links to the illicit cigarette trade (BAT, 2019).

Academic and civil society observers of the tobacco market claim that since 2006, the large multinationals have been deliberately exaggerating the size of the illicit market as a way to lobby against increases in excise duty, which the South African government has pursued to bring its policy into line with international recommendations and to curb the high rate of smoking. An industry group called the Tobacco Institute of Southern Africa (TISA) blamed the purported high and increasing level of illicit trade on the excise tax, which they claimed increased the incentive for criminal actors to enter into the tobacco trade and harmed the market position of multinationals. These claims are not borne out by research, however; in fact, these claims follow a global pattern which has seen multinational tobacco companies use the issue of illicit tobacco to lobby governments to lower taxes (TISA, 2018).

However, the same observers are in agreement that the scale of illicit activity in the cigarette market has escalated substantially between 2015 and 2018, which they believe to be the result of diminished state capacity due to corruption in South Africa. Between the 2014 and 2017 tax years, excise revenue from tobacco products fell by $16 \%$, the number of cigarette packs on which tax was paid fell by $27 \%$, yet the rate of consumption fell only slightly.

The quantity of taxed cigarettes legally sold and consumed continued to decline substantially in the past two years. For instance, in the 2017-2018 financial year, the number of taxed cigarette packs amounted to approximately 763 million - 
a drop of $26 \%$ over two years. This steep decrease cannot be explained by standard factors alone, such as the evolution of cigarette prices, disposable income, population dynamics, and tobacco control legislation. A possible explanation could thus be a significant increase in the illicit cigarette trade, yet reports by SARS of seizures of illicit cigarettes do not point to an increase in seizures. As SARS has not released consistent figures on its illicit cigarette seizures over the years, its Annual Report suggests that the tax year 2014-2015 seems to have been the high water mark for seizures, with 204 million individual cigarette sticks seized and almost 1,500 interventions against illicit traders. The rate of seizures increased sharply from R17.5 million in 2016 to R61.4 million in 2018. As stated above, this correlates with a serious diminishment of the state's capacity to investigate the illicit economy in general (SARS, 2018).

A recent study released by IPSOS, funded by TISA, concluded that South Africa loses R7 billion (\$590 million) per annum to the illicit cigarette trade, and that of the total cigarette market, around $20 \%$ of trade is illicit. However, these figures do not count losses to transfer pricing and tax-base erosion, nor do they take into consideration that rates of smoking would fall were there to be fewer low-cost products on the market. The calculation of the size of the illicit market is also complicated by the fact that most measures will only count a pack selling below the tax threshold as being illicit, but where brands are not competing for the bottom of the market, there is nothing to stop untaxed cigarettes being sold for prices above the tax threshold (TISA, 2018).

Our typology of the smuggling of cigarettes in South Africa distinguishes between what we term 'internal smuggling', which involves various methods for evading paying tax on the sale of goods, and 'cross-border smuggling' - both the conventional variety involving material goods and more intangible financial crimes.

\section{Internal smuggling}

The most prominent illicit modality in South Africa is the simple yet effective practice of under-declaring production to SARS. The undeclared surplus is then sold, tax-free, typically on the black market. This technique has been utilised by tobacco manufacturers globally for years. Factories in South Africa operate double shifts, running their machines at night, and/or they hide the true scale of their production by paying off customs officials and creating fraudulent paperwork. They make use of all the available gaps in SARS' monitoring of their 'bond' warehouses, for example, reusing invoices for one hundred cases of 
cigarettes for multiple deliveries of one hundred cases each time. Alternatively, they obscure the quantity of their production and avoid paying excise through round-tripping and ghost exports, i.e. claiming that stock has been exported when in fact it has been sold in the domestic market. Many of the companies that are undeclaring and using round-tripping have a business model that blends licit and illicit trading - often they have entire brands that are produced and accounted for entirely legally, although these account for a minority of their business. Academic research has found this combination of licit and illicit production and/or sales to be a feature of illicit cigarette markets in jurisdictions across the world (Haysom, 2019).

\section{Counterfeiting}

When cigarettes are counterfeited they are packaged in identical or near-identical branding to popular cigarette brands (typically the premium brands made by multinationals). In addition to this fraud, tax is not paid on these products. Counterfeiting was prevalent in the 1990s, but its occurrence was eclipsed, although not entirely eliminated, by under-declaration in the 2000s. Counterfeit cigarettes are also smuggled across borders (Case, 2013).

\subsubsection{Cross-border modalities}

\section{Cross-border smuggling}

As described above, a large proportion of illicit cigarette seizures are of Zimbabwe-manufactured cigarettes that have been smuggled over the border. Cigarettes have also been smuggled across the Namibian, Botswanan, and Mozambican borders, although they were not necessarily produced in these adjacent countries. The police's Directorate for Priority Crime Investigation (also recognised as the Hawks) lists cigarettes manufactured in Botswana (the Sasha and Caspian brands, produced by Benson Craig) and Mozambique (the Pall Mall and Safari brands, produced by BAT) as 'commonly smuggled'. Smuggled cigarettes have also been seized at seaports, although these all represent a minority of both recorded seizures and alleged illegal activities (BAT, 2019). 


\section{'Losing' stock in transit}

Surplus stock destined for a cross-border market is sometimes 'lost' while in transit, although in fact it has been smuggled into the market where it disappeared or into an adjacent market (as such, this can be internal or cross-border). For a cross-border example, this method was allegedly used in a recent case before the Namibian Supreme Court involving Benson Craig. Namibian authorities impounded a shipment of cigarettes, apparently bound for Namibia. Benson Craig claimed that the shipment had 'mistakenly' been marked as bound for Namibia, but instead was in transit to another destination, and therefore not subject to tax and had been unlawfully impounded. Benson Craig's arguments were upheld and the company won the case.

Although Benson Craig was vindicated, the alleged methodology has been deployed by others in the past so that cigarettes could be smuggled into either the Namibian or South African market and sold cheaply on the black market.

\section{Methodology}

\subsection{Description of the model}

The CGE model used in this study is a simplified illustration of the South African economy. The model depicts the connections and linkages between diverse economic agents in the economy of the country, which includes the production, factor, product markets and consumption. The rest of the world or foreign markets are incorporated through trade and foreign savings. This model belongs to the class of fixed-price general equilibrium models, used to evaluate the economic effects of exogenous changes in income and demand. In addition, the model permits for the observation of inter-temporal changes to the economy and its characteristics as well as the assessment of policy interference impacts as they evolve over time. In the process of running the model, the result of the simulation is updated each time using the solution values of the previous time. Capital stock is accumulated proportionally to the investment expansion in the previous time where the share of capital accrued by every single sector is dependent on the weighted average of sector productivity as well as the sector's initial share in capital stock. Economic expansion is usually affected by adjustments in factor supplies and productivity. Figure 4 below illustrates the theoretical framework of the CGE model and provides the linkages between various agents. 
Figure 4. Theoretical framework of the CGE model

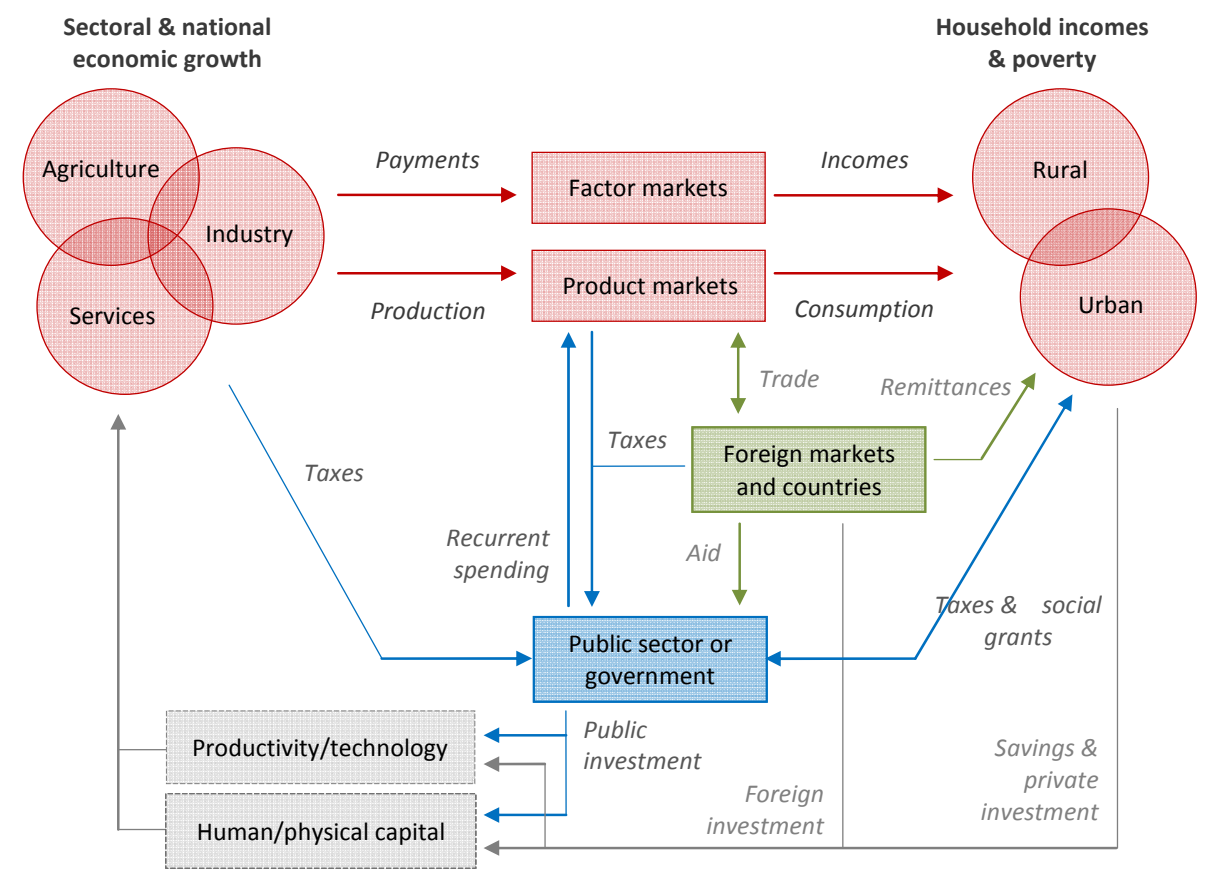

Source: Arndt, Davies, \& Thurlow (2011).

Figure 4 depicts the relationships between various economic agents in the economy. The CGE model takes into consideration all the significant South African taxes. It uses a Social Accounting Matrix (SAM) for the year 2015 as the database of the model, which reflects every economic transaction between all role players in the economy: companies, households, governments and, given international economic interactions, the Rest-of-World (ROW). Rows and columns in the SAM, known as 'accounts', reflect the inflows and outflows to each of these accounts (Alton et al., 2012).

The Standard CGE modelling framework identifies an account that represents 'enterprises'. This account receives earnings from the production factor capital which is then partly distributed to households, government and the rest of the world. After paying the tax, the saving can be considered. The tax can include the Secondary Tax on Companies (STC), thus in the Standard CGE modelling framework, corporate tax and STC are treated in aggregate. The accounts for households similarly reflect their income from enterprises and labour, expenditure, savings and the payment of direct tax which flows to government (Gemmell \& Hasseldine, 2012). 
The income that flows to and from the enterprise account includes income from dividends. Using South African Reserve Bank (SARB) data, a separate 'dividend account' can be added to the SAM, which reflects dividends paid out by corporate companies and the dividends received by corporate companies, households, government (a small amount) and the ROW, as well as STC on net dividends paid. Separating the flow of dividend income from other income flows to households makes it possible to apply a dividend tax to this income source (SARB, 2019).

There is a choice of various economic assumptions, known as 'closures', that are made in order to run a simulation in a CGE model. The main assumption is that the investment is guided by the savings. The marginal propensity to save for all nongovernment institutions is constant, while capital formation is elastic. When analysing STC and Dividend Tax (DT) impacts, we assumed flexible government savings, which means that changes in tax revenue to government are supposed to increase or decrease the government budget balance, while direct tax rates other than STC or DT rates are kept constant. We further adopted a variable exchange rate with constant foreign savings, and assumed that the skilled and unskilled labour pools do not grow, but that their wages can change. Various data obtained from various service providers are presented as follows:

- Government: Data are provided via the SARB's Public Finance division, which obtains actual data from the National Treasury (national and provincial government), Stats SA (local government) and in-house surveys.

- Rest of the World: Data are provided by the SARB's Balance of Payments division, which obtains its information from in-house surveys, the Johannesburg Stock Exchange (JSE) and other sources.

- Financial corporations: Sources include the banks' actual data received from the SARB's Money and Banking division, while pension and insurance data are provided by the SARB's Capital Markets and Flow of Funds division.

- Non-financial corporations: Sources include the JSE and the SARB's inhouse quarterly survey.

- Households: The JSE data provides an indication of growth and the level is the balance between the total economy and all the other institutional sectors mentioned above, as dividends paid must be equal to dividends received in the total economy. Moreover, note that dividends received by households include withdrawals from income of quasi-corporations, i.e. the owner(s) of a quasi-corporation can choose to withdraw some income from the business which must be classified under dividends. 
As indicated earlier, the SAM was used as the database for the CGE model. Various accounts can be depicted as follows:

\subsection{Production and consumption equations}

This model captures the comportments of producers and consumers established from the activities and commodities data. Consumers are assumed to maximise their utility based on the Stone-Geary utility function, subject to their budget constraint. The household is subdivided into 14 income categories by assuming that each income category is free to expand its welfare based on the available income (Case, 2013). The demand follows the Linear Expenditure System (LES) as illustrated in the Equation 3.1. The LES regulates the inconsistency of income elasticities between various household income categories.

$$
P_{j}^{*} H_{j h}=P_{j} * \gamma_{j h}+\beta_{j h} *\left(\left(1-\mathrm{S}_{h}-t d_{h}\right) * \mathrm{Y}_{h}-\Sigma_{j t} P_{j \prime} * \gamma_{j^{\prime} h}\right)
$$

while $H_{j h}$ signifies the expenditure on product $j$ by household $h, \beta_{j h}$ signifies the slight budget portion, $\gamma_{j h}$ signifies the smallest survival level, $P_{j}$ signifies the market price of each product, $Y_{h}$ signifies the gross household salary, $S_{h}$ signifies minimum savings and $t d_{h}$ signifies the direct tax rates.

Similarly, the assumption is that the producers should make enough revenue despite the fluctuation in the input and output prices. Based on the neoclassical theory, a constant elasticity of substitution (CES) function defines output quantity $\mathrm{A}$ from sector $\mathrm{j}$. In this case, the producer production function is illustrated by equation 3.2:

$$
A_{j}=a_{j} *\left(\delta_{j * L_{j}}{ }^{-\rho_{j}}+\left(1-\delta_{j}\right) * \bar{K}_{j}{ }^{-\rho_{j}}\right)^{-1 / \rho_{j}}
$$

while $\alpha$ signifies the total factor productivity (TFP), $\delta_{j}$ signifies the share, $\rho_{j}$ signifies the replacement parameter, $L_{j}$ signifies the labour and $K_{j}$ signifies the capital demand. It must be noted that the production function permits technologies to modify according to each economic activity. Maximising profits subject to equation 3.2 brings forth the subsequent factor demand as represented in equation 3.3:

$$
L_{j} / K_{j}=\left[\left(r * Z_{j} / W\right) *\left(1-\delta_{j} / \delta_{j}\right)\right]^{1 /\left(1+\rho_{j}\right)}
$$


where $W$ signifies the labour wage and $r$ signifies a fixed capital rental rate in the economy modified by a sector-specific element $Z$. The factor substitution elasticity is a transformation of $\rho$. Substitution can occur between labour and capital when relative prices change in the case of higher elasticities.

In this model, we assume that all factors are retained by households. Therefore, total household income is illustrated by equation 3.4:

$$
Y_{h}=\sum_{j}\left(\omega * W * L_{j}+\theta * r * Z_{j} * \bar{K}_{j}\right)+s t_{h}
$$

where $s t$ signifies social transfers from the government. Coefficients $\omega$ and $\Theta$ control the dissemination of factor earnings to individual households of labour and capital respectively. Provision is made in the model to incorporate enterprises that gain the returns to capital. The revenue received by the enterprises can be used to save, pay corporate taxes and dividends to households.

In the process of production, the intermediate demand in the model is based on the Leontief technology functions. Equation 3.5 captures the elements of intermediate demand. Fixed input-output coefficients $i o_{j j}$, display the quantity of good $j$ ' utilised to generate one unit of good $j$. These technical coefficients are derived from Stats SA (2017) and Arndt et al. (2011). Finally, the producer price, $P A$, is the sum of factor and intermediate payments per unit of output.

$$
P A_{j} * A_{j}=W * L_{j}+r * Z_{j} * \bar{K}_{j}+\sum_{j} P_{j} i o_{j j}
$$

\subsection{Sales tax and income}

Household is the biggest consumer and pays a huge amount of sales tax (VAT). VAT represents the purchaser tax as it is estimated from the value added by manufacturers and is proportional to the amount of VAT disbursed by purchasers. Nonetheless, the VAT disbursed by manufacturers on intermediate products must be subtracted due to the fact that the household income is composed of earnings from labour and capital offered. The earning from capital is proportional to the profit on capital minus depreciation (Dervis, de Melo, \& Robinson, 1982). The household earning is mathematically depicted in equation 3.6 below:

$$
Y_{h}(i)=Y_{P R I M}(i)+Y_{S E C}(i)+Y_{T E R T}(i)+Y_{C A P}(i)
$$


The variable $Y_{h}(i)$ in the equation 3.1 symbolises the household earning from industry i, while $Y_{P R I M}(i)$ represents the income obtained from the primary sector such as agriculture and mining, $Y_{S E C}(i)$ is the income from the secondary sector and $Y_{\text {TERT }}(i)$ is the income from the tertiary sector and $Y_{C A P}(i)$ is the income from the capital.

The sum of different taxes such as value added tax (VAT), household tax (HHTAX) and import tariffs (TARIFF) forms part of the government's revenue. Equation 3.7 represents the government revenue (YG):

$$
Y G=S U M(C, \operatorname{sub}(C) * P Q(C) * Q Q(C))+V A T+H H T A X
$$

While $\mathrm{PQ}(\mathrm{C})$ symbolises the price of composite good $\mathrm{C}$, $\operatorname{sub}(\mathrm{C})$ represents the subsidy rate applied on good $\mathrm{C}$ and $\mathrm{QQ}(\mathrm{C})$ is the quantity of composite goods supply. Equation 3.8 summarises the total government revenue (GR):

$$
\begin{gathered}
\mathrm{GR}=\mathrm{YG}+\mathrm{TARIFFEXPSUB}+ \\
\operatorname{TARIFFp}_{w m} \text { (c)* CM(c)* } t_{m} \text { (c) } E X R
\end{gathered}
$$

Where TARIFFEXPSUB represents the export subsidies, TARIFFp $p_{w m}(i)$ is the world price of exports, $\mathrm{C} M(\mathrm{c})$ symbolises the imported commodities, $t_{m}(i)$ is the rate of import tariff applied on the imported commodity from the rest of the world and EXR represents the exchange rate.

\subsection{Investment demand and government}

In the model, the government is regarded as a distinct establishment receiving revenue from direct tax $\left(\mathrm{td}_{\mathrm{h}}\right)$, indirect tax $\left(\mathrm{ts}_{\mathrm{j}}\right)$ and transfers to government $\left(\mathrm{st}_{\mathrm{g}}\right)$, as presented in the first part of equation 3.9:

$$
\Sigma_{h} t d_{h} * Y_{h}+\Sigma_{j} t s_{j} * P_{j} * Q_{j}+\sum s t_{g}=\Sigma_{j} P_{j} * G * g_{j}+\Sigma_{h} s t_{h}+B
$$

Usually the goods $g_{j}$ and social transfers' $s t_{h}$ can be procured when the revenue is available. B represents savings obtained from the remaining funds. This is adjusted to normalise the total revenues and expenditures, yet the expenditure is proportional to the quantity $g$ from the base-year times the exogenous adjustment factor $G$ in the model (Erero, 2015). 


\subsection{Expenditure on goods and services}

The consumption of cigarettes is included in the household consumption expenditure equation in the Standard CGE model, which shows that expenditure on goods and services is determined by income after savings, tax and transfers to other Institution Non-Governmental (INSDNG). In the original model this is written as (Gordon \& Li, 2005):

$$
E H_{h}^{\text {old }}=\left(1-\sum_{i=I N S D N G} s h i i_{i, h}\right)\left(1-M P S_{h}\right)\left(1-T I N S_{h}\right) Y I_{h}
$$

in which $E H^{\text {old }}{ }_{h}$ represents the expenditure of household $h$ and $s h i i_{i, h}$ represents the shares of net income transferred from households to other domestic non-government institutions (INSDNG). MPS $S_{i}$ is the savings rate for INSDNG. TINS represents the direct tax rate for domestic non-government institutions, while $Y I_{i}$ represents the income and $T R I I_{i,{ }^{\prime} D I V^{\prime}}$, the dividend payments received by all INSDNG from the dividend account. The philosophy of the model is not changed, but the payment of dividend tax by households in addition to a direct tax needs to be taken into account. Now accounting for dividend tax can be introduced by equation 3.11 (Horridge, 1993):

$$
E H_{h}^{\text {new }}=\left(1-\sum_{i=I N S D N G} s h i i_{i, h}\right)\left(1-M P S_{h}\right)\left[\left(1-\operatorname{TINS}_{h}\right) Y I_{h}+\left(T I N S_{h}-\operatorname{divt}_{h}\right) T R I I_{h, ' D I V^{\prime}}\right]
$$

\subsection{Closure}

In the macroeconomic closures, we assumed the following:

- Savings and investment: due to the reality of the country, we anticipated that savings are driven by the investment. In addition, the investment and government expenditure being fixed shares of absorption.

- Government: government savings are flexible with the repercussion that tax rates are fixed. The model allows for the option of changing the direct or indirect tax rate at a uniform or scaled rate.

- Current account: we assumed that the exchange rate should be flexible with the consequence that foreign savings are also flexible. 


\section{Simulation results}

We considered the loss of $\mathrm{R} 8$ billion in tax revenue at the current growth of the illicit cigarette trade. During the modelling exercise, we first set the tax rate for the dividend variable to $0 \%$. In doing so, we shocked the sales tax by this loss amount where we assumed there was a pool of unemployed unskilled labour which can become attached to any industry. All the results were assessed against the baseline scenario, which in this case reflected a situation relating to the business as usual set up. The simulation results for a selection of macro-economic variables are contained in Table 3 .

Table 3. Impact of the shock on the macro-economic variables

\begin{tabular}{|l|l|c|c|}
\hline \multicolumn{1}{|c|}{ Variable } & \multicolumn{1}{|c|}{ Description } & Base (2015 R billion) & Sim (\% change) \\
\hline ABSORP & Absorption & 2,690 & 0.03547 \\
\hline PRVCON & Consumption & 1,574 & -0.23990 \\
\hline FIXINV & Investment & 527 & 0 \\
\hline DSTOCK & Stocks & -3 & 0 \\
\hline GOVCON & Government consumption & 591 & -0.80000 \\
\hline EXPORTS & Exports & 645 & -0.07193 \\
\hline IMPORTS & Imports & -676 & 0.06871 \\
\hline GDPMP & GDP at market prices & 2,659 & -0.03588 \\
\hline NETITAX & Indirect taxes & 287 & -0.09615 \\
\hline EXRXY & Exchange rates & 1 & 0.00118 \\
\hline GDPFC & GDP at factor cost & 2,372 & -0.05185 \\
\hline
\end{tabular}

Source: Simulation results from the CGE model.

In column 3 of Table 3, we present numbers at base-year prices, while column 4 shows percentage differences from the base model run. The simulation results reflect the corresponding effect of losing R8 billion on the illicit cigarette trade on the South African economy. It can be seen that this has a minimal but negative impact on the related macro-economic variables, as GDP decreases slightly by $0.03588 \%$. This change off the base is not negligible.

The most important finding here is that at the national level, the illicit cigarette trade on its own certainly has a macroeconomic impact, as the direction of the results is portraying a negative effect. Both private and government consumption show a more substantial change: they decrease by $0.2399 \%$ and $0.8 \%$ respectively from the base level, causing a slight decrease in the net indirect tax $(0.09615 \%)$. As the indirect tax drops, this reduces government revenue. 
The slight increase in absorption and imports is clearly not enough to offset the government revenue losses caused by the illicit cigarette trade. Besides, the slight decrease in exports is justified as the rise in domestic demand in illicit cigarettes heightens domestic prices and manufacturers are in turn lured to reduce exports in line with the Constant Elasticity of Transformation (CET) function. Furthermore, the decrease in exports stimulated the improvement of the real exchange rate, which marginally reduced the exports by $0.07193 \%$. Table 4 includes the government income from the simulation results.

Table 4. Impact of the shock on the government income

\begin{tabular}{|l|c|c|}
\hline \multicolumn{1}{|c|}{ Income description } & Base (2015 R billion) & Sim (\% change) \\
\hline Direct revenue excl dividend tax & 396 & -0.05561 \\
\hline Activity tax revenues & 38 & 0.00005 \\
\hline Import duty revenues & 23 & 0.00076 \\
\hline Sales tax revenues & 226 & -0.00105 \\
\hline Transfers received from factors & 52 & 0.00021 \\
\hline Transfers received from ROW & -30 & -0.00023 \\
\hline
\end{tabular}

Source: Simulation results from the CGE model.

Table 4 indicates that sales tax revenue and direct revenue excluding dividend tax decreased by $0.00105 \%$ and $0.05561 \%$, respectively. Consequently, government revenue losses due to the illicit cigarette trade are almost, but not quite, offset by the marginal increase in activity tax and import duties. Thus, the sales tax has a considerable positive impact on government revenue, assuming that there are no behavioural changes from households. Furthermore, the tax base of the sales tax is wider than the dividend tax, as the latter is applied only to households and not to all dividends paid out, as is the case for sales tax. Table 5 includes the employment from the simulation results.

Table 5. Impact of the shock on the employment

\begin{tabular}{|l|l|c|c|}
\hline \multicolumn{1}{|c|}{ Variable } & \multicolumn{1}{|c|}{ Factor } & $\begin{array}{c}\text { Base } \\
\text { (2015 R billion) }\end{array}$ & $\begin{array}{c}\text { Sim } \\
\text { (\% change) }\end{array}$ \\
\hline flab-p & Labour with primary school education (grades 1-7) & 0.034 & -0.01294 \\
\hline flab-m & Labour with middle school education (grades 8-11) & 0.065 & -0.02736 \\
\hline flab-s & Labour completed secondary school education (grade 12) & 0.083 & -0.05376 \\
\hline flab-t & Labour with tertiary education (certificates, diplomas or degrees) & 0.158 & -0.10757 \\
\hline fcap & Capital & 0.358 & 0 \\
\hline
\end{tabular}

Source: Simulation results from the CGE model. 
Table 5 reports the factor income by income categories. Bearing in mind the actual condition of the South African labour market where the unemployment rate is high, we considered that capital and labour with tertiary education is altogether employed, while labour with primary, middle and secondary school education are unemployed. In this respect, the nominal wages for labour with primary, middle and secondary school education will be invariable as their factors are subjected to substantial levels of unemployment. Our findings show that labour demand decreases amongst all factor income by income categories due to the growth of the illicit cigarette trade. Table 6 includes the effects of the illicit cigarettes on the household consumption from the simulation results.

Table 6. Impact of the shock on the household consumption

\begin{tabular}{|l|l|c|c|}
\hline \multicolumn{1}{|c|}{ Variable } & \multicolumn{1}{|c|}{ Description } & Base (2015 R billion) & Sim (\% change) \\
\hline hhd-0 & Decile 1 & 27 & 0.0663 \\
\hline hhd-1 & Decile 2 & 46 & -0.0329 \\
\hline hhd-2 & Decile 3 & 56 & -0.0473 \\
\hline hhd-3 & Decile 4 & 64 & -0.0512 \\
\hline hhd-4 & Decile 5 & 76 & -0.0642 \\
\hline hhd-5 & Decile 6 & 88 & -0.0616 \\
\hline hhd-6 & Decile 7 & 107 & -0.0605 \\
\hline hhd-7 & Decile 8 & 150 & 0.4267 \\
\hline hhd-8 & Decile 9 & 287 & 0.3770 \\
\hline hhd-91 & Percentile 90-92 & 84 & 0.3415 \\
\hline hhd-92 & Percentile 92-94 & 98 & 0.3146 \\
\hline hhd-93 & Percentile 94-96 & 117 & 0.6620 \\
\hline hhd-94 & Percentile 96-98 & 142 & 0.7742 \\
\hline hhd-95 & Percentile 98-100 & 229 & 1.4770 \\
\hline
\end{tabular}

Source: Simulation results from the CGE model.

Table 6 gives the simulation results for the real household consumption, where the households have been grouped in income deciles (hhd-0 to hhd-8), with the highest income decile split into two-percentile groupings (hhd-91 to hhd95). Reading the simulations from left to right, one can see that the illicit cigarette trade benefits higher earning households while harming lower earning household groups, but that as the consumption of the illicit cigarette trade increases, the impact reverses.

Based on the selection of the macroeconomic adjustment criteria, low income households lose out with the consumption of illicit cigarettes for the main reason that the decline in government revenue has a negative effect on entire savings. In this respect, they are obliged to augment their savings (in order to 
maintain investment at the base level) and spend less. This also relates to high income households, although their tax burden declined substantially, mostly because of the income distribution design. In this way, the low prices of the illicit cigarettes will offset the preliminary consumption shortfalls attributable to higher savings, but a lower tax burden turns it into a gain.

Overall, it would appear that the effects of illicit cigarettes may cause a minimal sharing of income between high and low income households. As mentioned earlier, our analysis is based on losses of R8 billion in tax revenue at the current expansion of the illicit cigarette market assumed to benefit the households. Table 7 includes the effects of the illicit cigarettes on the sectoral output from the simulation results.

Table 7. Impact of the shock on the sectoral output

\begin{tabular}{|l|c|c|}
\hline \multicolumn{1}{|c|}{ Sector } & Base (2015 R billion) & Sim (\% change) \\
\hline Agriculture & 2 & -0.1797 \\
\hline Mining & 10 & 0.0597 \\
\hline Manufacturing & 14 & 0.1020 \\
\hline Other industries & 6 & 0.0559 \\
\hline Private services & 48 & 0.0794 \\
\hline Public Services & 19 & -0.6086 \\
\hline
\end{tabular}

Source: Simulation results from the CGE model.

Following the effects of the illicit cigarette trade on the sectoral output, Table 7 indicates that agriculture and public services are the hardest hit with consideration of unemployed labour resources, i.e. outputs decrease by $0.1797 \%$ and 0.6086 respectively. With consideration of unemployed labour resources, the negative impact of the illegal cigarette trade is somewhat intensified when unemployment is assumed for lower skilled labour because the agriculture sector absorbs the largest number of lower skilled labour. Sectors which profit from the illicit cigarette trade comprise manufacturing, mining, private services and other industries.

\section{Policy implications}

It is evident that over the years, less effort has been made to fight the traffic of illicit cigarettes by the three spheres of government, i.e. local, provincial and national. Consequently, the illicit cigarette trade is the most gainful economic activity amongst the street vendors in South Africa. Illicit cigarette sales have 
increased considerably across all small retailers in South Africa. In spite of this, no laws have been enforced to reduce the smuggling of illicit cigarettes. This weakens trust in established laws and encourages the evolution of coordinated lawbreakers. Our recommendation is that the South African government create additional legislation that addresses the importation of wide-ranging cigarette filing devices and manufacturing machinery. Another recommendation is the implementation of a specific Cigarette Governing Body, with a distinct area of accountability that focuses solely on illicit cigarette trade.

\section{Conclusions}

This study evaluated the effects of the illicit cigarette trade on the South African economy. This trade occupies a prominent place in public debate in South Africa, both regarding crimes that may have been committed in the last five years, and how the current administration should respond to the current illicit economy. The static CGE model was used to perform this study. We made a choice of various economic assumptions, known as 'closures', that were made in order to run a simulation in the model. We assumed that the investment is constrained by the savings. The fraction of additional income that is used for saving for nongovernment organisations is constant, while investment remains variable. Savings rate is the other significant variable that induces the adjustment in tax rates. One policy simulation was carried out to evaluate the effects of the illicit cigarette trade on the economy, as South Africa is losing a substantial amount in tax revenue given the ongoing growth of the illicit cigarette trade.

The simulation results corresponding to the effect of losing R8 billion due to the illicit cigarette trade on the South African economy had a small but negative effect on the described macro-economic indicators. GDP decreased slightly by $0.03588 \%$, which is not negligible. The important lesson here is that the illicit cigarette trade on its own certainly has a macroeconomic impact, as the direction of the results suggests it has a negative effect. Both private and government consumption show a more substantial change: they decrease by $0.2399 \%$ and $0.8 \%$, respectively, from the base level, causing a slight decrease in the net indirect tax $(0.09615 \%)$. Nonetheless, the labour demand decreased across all factor income by income categories due to the growth of the illicit cigarette trade. Reading the simulation results from left to right, one sees that the illicit cigarette trade benefits mostly higher earning households while harming lower earning households, but that as the consumption of illicit cigarettes increases, the impact reverses. 
The low income households lose out with the consumption of illicit cigarettes due to the decline in government revenue, which impacts negatively on total savings. In this respect, these low income households are obliged to augment their savings (with the aim of maintaining investment at the base level) and spend less.

Overall, it would appear that the effects of the illicit cigarette trade may cause a minor shift in consumption between low and high income households. In fact, as mentioned in the methodology, our analysis is based on losses of R8 billion in tax revenue given the current growth of the illicit cigarette market assumed to benefit households. This paper contributes to expanding awareness among policymakers and the public of the connection between the illicit trade in licit goods, corruption, and organised criminal networks. As this study was limited to the assessment of the losses of tax revenue from the illicit cigarettes, further study will require a specific analysis of the laws that should be enforced to reduce the smuggling of the illicit cigarettes in the country.

\section{References}

Abedian, I., \& Jacobs, R. (2001). Tobacco taxes and government revenue in South Africa. Journal of Economic Studies, 28(6), 397-407. https://doi.org/10.1108/EUM00000 00006275

African Tax Outlook. (2018). Taxation (2nd ed.). Retrieved from https://events.ataftax. org/index.php?page $=$ documents\&func $=$ view\&document_id $=17$

Aizenman, J., \& Jinjarak, Y. (2005). The collection efficiency of the value added tax: Theory and international evidence. Santa Cruz: Department of Economics, University of California. https://doi.org/10.1080/09638190802137059

Alton, T., Arndt, C., Davies, R., Hartley, F., Makrelov, K., Thurlow, J., \& Ubogu, D. (2012). The economic implications of introducing carbon taxes in South Africa (Working Paper, No. 2012/46). Helsinki: UNU-WIDER World Institute for Development Economics Research

Arndt, C., Davies, R., \& Thurlow, J. (2011). Energy extension to the South Africa General Equilibrium (SAGE) Model (Version 2.0). Helsinki: UNU-WIDER (Unpublished mimeo).

Bankman, J., \& Schler, M. (2007). Tax planning under the flat tax. In H. J. Aaron, L. E. Burman, \& C. Eugene Steuerle (Eds.), Taxing capital income (pp. 245-284). Washington, DC: Urban Institute Press.

Becker, G. S., \& Murphy, K. M. (1988). A theory of rational addiction. Journal of Political Economy, 96(4), 675-700. Retrieved from https://www.journals.uchicago. edu/doi/citedby/10.1086/261558 
British American Tobacco [BAT]. (2019). News release. Retrieved from https:// www.bat.com/group/sites/UK_9D9KCY.nsf/vwPagesWebLive/DOBCZHE4

Case, A. (2013). Study to quantify and analyse the VAT gap in the EU-27 Member States. TAXUD/2012/DE/316. Warsaw: Center for Social and Economic Research.

Coats, R. M. (1995). A note on estimating cross-border effects of state cigarette taxes. National Tax Journal, 48(4), 573-584. Retrieved from https://www.jstor.org/stable/41789173

Dervis, K., de Melo, J., \& Robinson, S. (1982). General equilibrium models for development policy. New York, NY: Cambridge University Press.

Erero, J. L. (2015). Effect of increase in Value Added Tax: A dynamic CGE approach (Working Paper, No. 558). Cape Town: Economic Research Southern Africa,.

Euromonitor International. (2017). Cigarettes in South Africa. Retrieved from http:// tobaccotactics.org/index.php?title=South_Africa-_Country_Profile\#cite_ref-em_6-2

Gemmell, N., \& Hasseldine, J. (2012). The tax gap: A methodological review (Working Paper, No. 09/2012). Kelburn: Victoria University.

Gold Leaf Tobacco Corporation [GLTC]. (2018). Gold Leaf Tobacco denies tax evasion, blames BAT. Retrieved from https://citizen.co.za/news/south-africa/1972599/goldleaf-tobacco-denies-tax-evasion-blames-bat/

Gordon, R., \& Li, W. (2005). Tax structure in developing countries: Many puzzles and a possible explanation (Working Paper, No. 11267). Cambridge, MA: NBER.

Guindon, G. E., Paraje, G. R., \& Chaloupka, F. J. (2016). The impact of prices and taxes on the use of tobacco products in Latin America and the Caribbean. Revista Panamericana de Salud Publica, 40(4), 272-284. Retrieved from https:/www.ncbi.nlm. nih.gov/pubmed/28001204

Haysom, S. (2019). The illicit tobacco trade in Zimbabwe and South Africa: Impacts and solutions (Working Paper). Atlantic: Atlantic Council. Retrieved from https:// www.atlanticcouncil.org/in-depth-research-reports/issue-brief/the-illicit-tobaccotrade-in-zimbabwe-and-south-africa/

Herald, R. (2015). Horse trailer jam-packed with illegal cigarettes seized at SA-Zim border post. Retrieved from https://www.dispatchlive.co.za/news/2015-09-30horse-trailer-jam-packed-with-illegal-cigarettes-is-seized-at-sa-zim-border/

Horridge, J. M., Parmenter, B. R., \& Pearson, K. R. (1993). ORANI-G: A general equilibrium model of the Australian economy (Centre of Policy Studies/IMPACT Centre Working Papers, op-93). Melbourne: Centre of Policy Studies/IMPACT Centre, Victoria University. Retrieved from https://ideas.repec.org/p/cop/wpaper/ op-93.html

Huang, B.-N., \& Yang, C.-W. (2006). Demand for cigarettes revisited: An application of the threshold regression model. Agricultural Economics, 34(1), 81-86. https://doi. org/10.1111/j.1574-0862.2006.00105.x

KPMG. (2018). Illicit tobacco in Australia: Full year report. Retrieved from https:// www.stopillegal.com/docs/default-source/external-docs/kpmg-illicit-tobacco-innew-zealand-2018-full-year-report-(may-2019).pdf 
Malcolm, R. (2013). Mugabe link to illegal cigarette trade. Sunday Times, December 23. Retrieved from https://www.timeslive.co.za/sunday-times/lifestyle/2013-12-29mugabe-link-to-illegal-cigarette-trade/

Mukong, A. K., \& Tingum, E. N. (2018). The demand for cigarettes: New evidence from South Africa (Working Paper, No 227). Cape Town: Southern Africa Labour and Develop Research Unit (SALDRU).

OECD. (2017). Tax database. Retrieved from https://www.oecd.org./tax/tax-policy/taxdatabase/

Rezayatmand, R., Groot, W., \& Pavlova, M. (2017). Smoking behaviour and health care costs coverage: An European cross-country comparison. International Journal of Health Economics and Management, 17(4), 453-471. https://doi.org/10.1007/s10 754-017-9218-8

Rohan Pike Consulting. (2017). Submission to parliamentary inquiry into illicit tobacco. Retrieved from https://www.aph.gov.au/Parliamentary_Business/Committees/Joint

South Africa Reserve Bank [SARB]. (2019). Quarterly bulletin. Retrieved from https:// www.resbank.co.za/Lists/News\%20and\%20Publications/Attachments/9632/01Full $\% 20$ Quarterly\%20Bulletin.pdf

South Africa Revenue Service [SARS]. (2018). South African tax statistics (national publication). Retrieved from https://www.sars.gov.za/AllDocs/Documents/Tax\% 20Stats/Tax\%20Stats\%202018/Tax\%20Statistics\%202018.pdf

Stats SA. (2017). Annual financial survey. Retrieved from http://www.statssa.gov.za /publications/P0021/P00212017.pdf

Tobacco Institute of Southern Africa [TISA]. (2018). Take back the tax. Retrieved from https://web.archive.org/web/20180913120755/http://www.takebackthetax.org/

Vellios, N., \& van Walbeek, C. (2016). Determinants of regular smoking onset in South Africa using duration analysis. BMJ Open, 6(7), e011076. Retrieved from https://www.ncbi.nlm.nih.gov/pubmed/27431900

World Health Organisation [WHO]. (2019). Illegal trade of tobacco products. What you should know to stop it. Retrieved from https://www.who.int/news-room/fact-sheets/ detail/tobacco 